\title{
Temporomandibular Disorders in Patients Undergoing Mandibular Advancement Device Therapy for Obstructive Sleep Apnea: A Systematic Review
}

\author{
Amanda Phoon Nguyen ${ }^{1 *}$ and Ramesh Balasubramaniam ${ }^{1}$ \\ Received: 6 April 2016; Returned for revision: 26 May 2016; Received in revised form: 13 Aug 2016; \\ Accepted: 3 September 2016; Published online: 1 October 2016 \\ (C) The author(s) 2016. Published with open access at www.uscip.us
}

\begin{abstract}
Background: Mandibular advancement device (MAD) therapy is a popular and effective treatment for snoring and obstructive sleep apnea (OSA). However, there have been several reports in the literature of patients developing temporomandibular disorders (TMDs).

Objective: The objective of this review is to evaluate the prevalence of TMD, both in the initial phase of therapy and at follow up appointments, amongst patients wearing a MAD for OSA.

Methods: The authors conducted a systematic review of published articles in which the presence of TMDs in patients undergoing MAD therapy for OSA was investigated. Eligible studies met the following criteria: a diagnosis of TMD following mandibular advancement using a custom-made and titratable MAD using either the Diagnostic Criteria for TMD (DC/TMD), Helkimo Anamnestic Dysfunction Index or reproducible clinical signs/symptoms. Of the thirty-six articles published in this area, eleven were included in this review. These were assessed in accordance with the Preferred Reporting Items for Systematic reviews and Meta-Analyses (PRISMA) guidelines.
\end{abstract}

Results: The average prevalence of TMD during the initial phase of MAD therapy was found to be $25 \%$. The prevalence of TMD reduced in the follow up periods. The adherence to MAD, especially long term, appears to be variable and from our results, it appears an average of $20 \%$ of patients discontinue MAD therapy over six to one hundred and twenty months, and this number has been reported to be as high as $62.5 \%$ (over 58 months).

Conclusions: There was some difficulty in comparing the studies due to the differences in follow up time, methodology, sample size and diagnostic criteria. Longer clinical follow-up studies, with an objective method of monitoring patient adherence such as home monitoring devices, and preferably with a larger sample size

*Corresponding e-mail: phoonamanda@gmail.com

1 Oral Medicine Clinic, School of Dentistry, University of Western Australia, Crawley, Western Australia 


\section{Amanda Phoon Nguyen and Ramesh Balasubramaniam / American Journal of Oral Medicine}

(2016) Vol. 2 No. 1 pp. 26-42

are needed to evaluate the long-term effects of MADs on the TMD. The authors consider it prudent for clinicians to counsel patients that a small number will experience signs and symptoms of TMD with MAD use. However TMD is usually transient and the long-term risk appears small. In patients who develop TMD during MAD therapy, treatment of their TMD is recommended to prevent discontinuation of MAD therapy. In a few patients, persistent TMD may result in discontinuation of MAD therapy. Patients should be cautioned of this possibility and subsequently referred to consider other treatment options for their OSA.

Keywords: Temporomandibular Disorders; Mandibular Advancement Therapy; Mandibular Advancement Device; Obstructive Sleep Apnoea; Sleep Apnea

\section{Introduction}

Obstructive sleep apnea (OSA), a sleep disorder characterized by recurring collapse of the upper airway during sleep, is defined by the occurrence of five or more episodes of complete (apnea) or partial (hypopnea) upper airway obstruction per hour of sleep (Sutherland et al., 2014). OSA, and resultant sleep fragmentation and oxygen desaturation, have been associated with daytime sleepiness, cognitive impairment, type 2 diabetes, cardiovascular disease, stroke, increased risk of motor vehicle accidents and can have significant effects on quality of life (Chen et al., 2008; Cunali et al., 2008; Sutherland et al., 2014; Vuorjoki-Ranta et al., 2014). It can affect $4 \%$ to $9 \%$ of the middle-aged population, and some studies report an incidence as high as $34 \%$ in men (Clark et al., 2000; Cunali et al., 2008). Sufferers require an effective and long-term treatment.

The gold standard treatment for OSA is to pneumatically splint the upper airway during sleep using continuous positive airway pressure (CPAP) (Sutherland et al., 2014). Although CPAP is highly efficacious in preventing upper airway collapse, providing a successful outcome in over $95 \%$ of users, as many as $50 \%$ of patients cannot tolerate the use of CPAP (Perez et al., 2013; Sutherland et al., 2014). Hence many patients look toward alternative treatment options, such as the use of a mandibular advancement device (MAD).

The current clinical practice guideline of the American Academy of Sleep Medicine (AASM) and American Academy of Dental Sleep Medicine (AADSM) recommends that adult patients without OSA, who request treatment of primary snoring, be prescribed oral appliances, rather than no therapy (Ramar et al., 2015). For adult patients with OSA, both oral appliances and CPAP can significantly reduce the apnea-hypopnea index/respiratory disturbance index/respiratory event index (AHI/RDI/REI) across all levels of OSA severity in adult patients (Ramar et al., 2015). CPAP remains first-line therapy for the treatment of adult patients with severe OSA; however, it is recommended that patients who are intolerant of CPAP therapy or prefer alternate therapy be provided with an oral appliance, rather than no treatment (Ramar et al., 2015). Though there is limited evidence for further recommendations, based on a single retrospective study by Holley in 2011, there was no significant difference in the percentage of mild OSA patients achieving their target AHI/RDI/REI $(<5,<10,>50 \%$ reduction) after treatment between OAs and CPAP (Ramar et al., 2015). MAD use instead of CPAP therapy may prove to be more acceptable for patients with chronically impaired nasal ventilation, frequent travelers who prefer the convenience of a MAD, and for residents of areas where electrical power is not available (Mehta et al., 2001; Napankangas et al., 2012). 


\section{Amanda Phoon Nguyen and Ramesh Balasubramaniam / American Journal of Oral Medicine}

(2016) Vol. 2 No. 1 pp. 26-42

The MAD aims to create a widening of the upper airway configuration by posturing the mandible forward. This action changes the dimensions of the upper airway, including the hypopharynx, the oropharynx, and the nasopharynx, and imaging studies have shown that the upper airway space expands, most notably in the lateral dimension of the velopharyngeal region (Bondemark, 1999; Sutherland et al., 2014). It has been also hypothesized that MADs increase muscular tonus by increasing the passive muscle tension in the pharyngeal wall, thereby reducing the vibration of the soft tissues and the turbulent airflow (Hammond et al., 2007). Assessment of pharyngeal collapsibility during mandibular advancement therapy has also shown a dose-dependent effect in improvement of upper airway closing pressures (Sutherland et al., 2014). When oral appliance therapy is prescribed for an adult patient with OSA, a custom, titratable appliance is recommended (Ramar et al., 2015).

Although MAD therapy has been shown to be effective in the treatment of OSA, its use may be associated with side effects. Beneficial treatment effects may be reduced by treatment-related side effects, and ultimately the lack of adherence to treatment (Ramar et al., 2015). Excessive salivation, dry mouth, and pain or discomfort in the supporting teeth, oral mucosa, masticatory muscle, and temporomandibular joint (TMJ) have been reported as temporary side effects during short and medium periods of oral appliance use (Mehta et al., 2001; Hammond et al., 2007; Cunali et al., 2009; Marklund, 2015)

Long-term side effects include occlusal changes without the presence of pain, and skeletal changes (Cunali et al., 2009; Marklund, 2015) Most of these short to medium term side effects are transient and often treatable (Cunali et al., 2009; Hammond et al., 2007). It is purported that by inducing a forward and downward position of the mandible and maintaining it in a non-habitual position during sleep, the harmony of the stomatognathic system is potentially affected, with subsequent development of signs and symptoms of TMD (Mehta et al., 2011; Napankangas et al., 2012; De Leeuw and Klasser, 2013; Perez at el., 2013).

The American Academy of Orofacial Pain (AAOP) defines TMD as "a collective term for a group of musculoskeletal and neuromuscular conditions which includes several clinical signs and symptoms involving the muscles of mastication, the TMJ, and associated structures (De Leeuw and Klasser, 2013). In a recent update, the American Academy of Orofacial Pain divided TMD in two broad categories: TMJ disorders and masticatory muscle disorders (De Leeuw and Klasser, 2013). TMD affects $5 \%$ to $12 \%$ of the population, and typically affects the middle-aged population, occurring more frequently in women (Cunali et al., 2009; Doff et al., 2012).

These disorders are principally characterized by pain in the temporomandibular region or in the muscles of mastication, functional limitations or deviations in mandibular range of motion and TMJ sounds during jaw function (Carrara et al., 2010; Napankangas, 2012). The symptoms most often reported by patients include pain in the face, TMJ, masticatory muscles and pain in the head and ear (Carrara et al., 2010; Napankangas, 2012). The signs are primarily muscle and TMJ tenderness to palpation, limitation and/or incoordination of mandibular movements and joint noises (Carrara et al., 2010). The presence of TMD may result in poor adherence or even discontinuation of treatment. Hence its early diagnosis and treatment is necessary. 


\section{Amanda Phoon Nguyen and Ramesh Balasubramaniam / American Journal of Oral Medicine}

(2016) Vol. 2 No. 1 pp. 26-42

This systematic review evaluates the prevalence of TMD, a known side effect in patients with OSA after the commencement of MAD therapy, and also to establish whether the TMD is transient in this group of patients. The presence of TMD may result in poor adherence or even discontinuation of treatment. Hence its early diagnosis and treatment is necessary to improved adherence to treatment.

\section{Methods}

The authors conducted a systematic review of published papers in which the presence of TMDs in patients undergoing MAD therapy for OSA was investigated.

\subsection{Eligibility criteria}

Eligible studies met the following criteria: diagnosis of TMD following MAD using a MAD, using the Diagnostic Criteria for TMD (DC/TMD), Helkimo Anamnestic Dysfunction Index or clinical signs/symptoms. As there were several MAD designs employed in the studies, only devices with a minimum of $50 \%$ initial advancement of the device were included.

\subsection{Information sources and search}

We conducted a computerized search of databases Medline, PubMed, the Cochrane Library database and Google Scholar for papers published from 1965 through to January 2016, using the search terms 'Temporomandibular Disorders' AND/OR 'Mandibular Advancement' AND/OR 'Anterior Repositioning' AND/OR ‘Oral Appliance Therapy’ AND ‘Obstructive Sleep Apnoea/Apnea’.

\subsection{Study selection}

One reviewer searched titles and abstracts of identified published citations in the search results. Also the reference lists of these articles were searched. Thirty-six studies were screened. After the eligibility criteria were applied, eleven studies were found suitable and these were reviewed in its entirety. These were assessed in accordance with the Preferred Reporting Items for Systematic reviews and Meta-Analyses (PRISMA) guidelines.

Using standardized forms, the primary author extracted data from the studies independently, which included number of participants at the beginning and end of the study, demographic information and gender of participants, methodology and how the diagnosis of TMD was reached, its prevalence, MAD design, and whether the patients judged the outcome to be beneficial.

There was substantial diversity found in the outcome measures used among eligible trials. 
Amanda Phoon Nguyen and Ramesh Balasubramaniam / American Journal of Oral Medicine

(2016) Vol. 2 No. 1 pp. 26-42

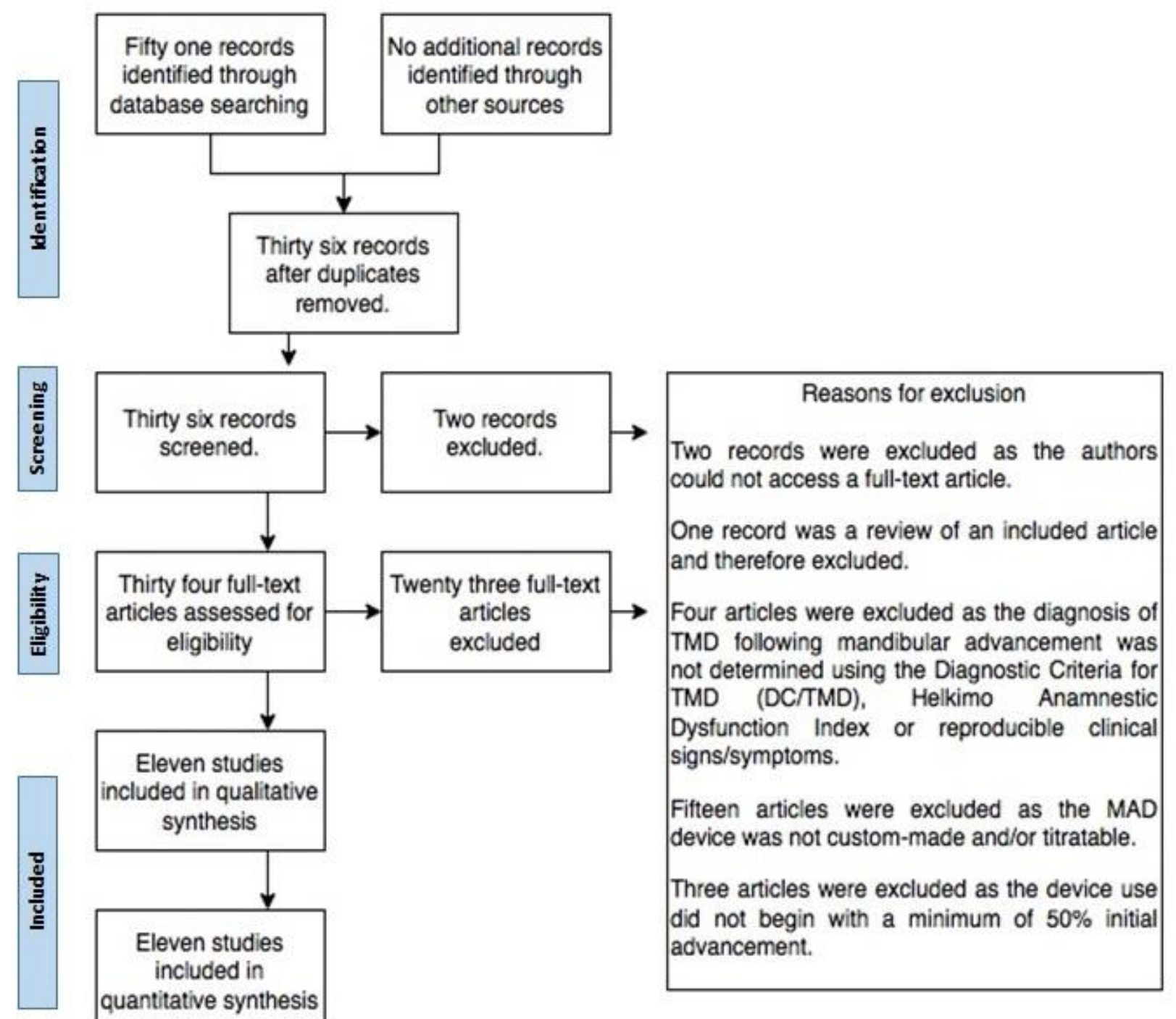

Fig. 1. Flow of information through the different phases of the systematic review.

\section{Results}

The studies found suitable were reviewed and the following results are collated and tabulated (Table 1, Table 2, and Table 3). 
Amanda Phoon Nguyen and Ramesh Balasubramaniam / American Journal of Oral Medicine

(2016) Vol. 2 No. 1 pp. 26-42

Table 1 Prevalence of TMD (Initial and Final) Across the Studies

\begin{tabular}{|c|c|c|c|c|c|}
\hline Study & $\begin{array}{c}\text { Total } \\
\text { number of } \\
\text { patients }\end{array}$ & $\begin{array}{c}\text { TMD } \\
\text { Prevalence } \\
\text { (Initial) }\end{array}$ & $\begin{array}{c}\text { TMD } \\
\text { Prevalence } \\
\text { (Final) } \\
\end{array}$ & $\begin{array}{l}\text { Time } \\
\text { Period }\end{array}$ & $\begin{array}{c}\text { Diagnostic Criteria /Signs } \\
\text { and Symptoms to reach } \\
\text { diagnosis }\end{array}$ \\
\hline $\begin{array}{l}\text { Almeida et } \\
\text { al., } 2002\end{array}$ & 7 & $14 \%$ & $\begin{array}{l}14 \% \\
1 \text { patient } \\
\text { developed with } \\
\text { articular pain of } \\
\text { right TMJ. }\end{array}$ & $\begin{array}{l}1.5 \\
\text { months } \\
\text { (40 days) }\end{array}$ & $\begin{array}{l}\text { Polysomnographic } \\
\text { recordings were performed. } \\
\text { A dentist performed the } \\
\text { dental evaluation of the } \\
\text { inclusion and exclusion } \\
\text { criteria for MAD use. } \\
\text { Patients were eligible only if } \\
\text { they had no symptoms } \\
\text { related to TMD and had a } \\
\text { body mass index (BMI) less } \\
\text { than } 33 \mathrm{~kg} / \mathrm{m} 2 \text {. } \\
\text { To investigate the anatomy } \\
\text { and position of the condyle } \\
\text { and disc of the TMJ, MRI of } 7 \\
\text { patients was obtained before } \\
\text { insertion of the appliance } \\
\text { and after OA titration. }\end{array}$ \\
\hline $\begin{array}{l}\text { Bondemark } \\
\text { and } \\
\text { Lindman, } \\
2000\end{array}$ & 32 & $0 \%$ & $\begin{array}{l}0 \% \\
37 \% \text { of patients } \\
\text { reported jaw } \\
\text { joint pain and } \\
30 \% \text { of patients } \\
\text { reported jaw } \\
\text { muscle pain. }\end{array}$ & 24 months & $\begin{array}{l}\text { Patients answered questions } \\
\text { based on the Helkimo } \\
\text { anamnestic index, as well as } \\
\text { questions regarding } \\
\text { headache frequency. } \\
\text { Clinical exam assessed the } \\
\text { range of movement of the } \\
\text { mandible, the function of the } \\
\text { TMJ, pain on movement of } \\
\text { the mandible, and pain on } \\
\text { palpation of the TMJ and the } \\
\text { masticatory muscles. } \\
\text { Study casts were also taken } \\
\text { before and after the } 2 \text { years } \\
\text { of MAD therapy. }\end{array}$ \\
\hline $\begin{array}{l}\text { Clark et al., } \\
2000\end{array}$ & 53 & $37 \%$ & $\begin{array}{l}\text { Up to } 40 \% \text { of } \\
\text { responding } \\
\text { patients, } \\
\text { reported } \\
\text { jaw/facial } \\
\text { muscle pain } \\
\text { and/or jaw joint. }\end{array}$ & $\begin{array}{l}12 \text { to } 36 \\
\text { months }\end{array}$ & $\begin{array}{l}\text { A telephone and mail survey } \\
\text { was done at least } 1 \text { full year } \\
\text { after device therapy, and } \\
\text { patients were asked to } \\
\text { indicate what discomforts } \\
\text { and the frequency with } \\
\text { which they experienced it. }\end{array}$ \\
\hline $\begin{array}{l}\text { Cunali et al., } \\
2009\end{array}$ & 87 & $52 \%$ & NR & NR & $\begin{array}{l}\text { Axis I (RDC/TMD): Clinical } \\
\text { Physical Examination was } \\
\text { used to diagnose TMD. } \\
\text { Axis II (RDC/TMD): } \\
\text { Biobehavioral } \\
\text { Questionnaires, from the }\end{array}$ \\
\hline
\end{tabular}




\begin{tabular}{|c|c|c|c|c|c|}
\hline & & & & & $\begin{array}{l}\text { Scoring Protocol for Graded } \\
\text { Chronic Pain index, were } \\
\text { used to classify pain } \\
\text { according to its intensity and } \\
\text { the pursuant limitation. } \\
\text { All patients completed the } \\
\text { Axis II: Biobehavioral } \\
\text { Questionnaires. } \\
\text { A clinical examination used } \\
\text { for confirmation and } \\
\text { classification of TMD was } \\
\text { carried out according to the } \\
\text { Axis I: Clinical Physical } \\
\text { Examination Forms and } \\
\text { specifications of the } \\
\text { RDC/TMD. }\end{array}$ \\
\hline $\begin{array}{l}\text { Fritsch et al., } \\
2001\end{array}$ & 22 & $36.3 \%$ & $0 \%$ & $\begin{array}{l}12-30 \\
\text { months }\end{array}$ & $\begin{array}{l}\text { All of the } 22 \text { patients } \\
\text { reported minor side effects. } \\
9 \text { reported jaw pain and } 8 \\
\text { reported stiffness or pain of } \\
\text { masticatory muscles. } \\
\text { After } 12 \text { to } 30 \text { months of } \\
\text { MAD therapy, symptoms and } \\
\text { side effects were evaluated } \\
\text { using a questionnaire. A } \\
\text { clinical dental examination, } \\
\text { a lateral cephalography, wax } \\
\text { bites, and plaster models } \\
\text { were carried out. }\end{array}$ \\
\hline $\begin{array}{l}\text { Giannasi et } \\
\text { al., } 2009\end{array}$ & 42 & $5.8 \%$ & $\begin{array}{l}0 \% \\
2 \text { patients } \\
\text { reported TMJ } \\
\text { discomfort } \\
\text { lasting for the } \\
\text { first } 6 \text { months. } 3 \\
\text { patients } \\
\text { reported that the } \\
\text { TMJ noises had } \\
\text { disappeared and } \\
3 \text { patients } \\
\text { exhibited } \\
\text { decreased } \\
\text { frequency in TMJ } \\
\text { noises. }\end{array}$ & $\begin{array}{l}36+/-17 \\
\text { months }\end{array}$ & $\begin{array}{l}\text { Patients responded to a } \\
\text { questionnaire based on the } \\
\text { Helkimo Anamnestic } \\
\text { Dysfunction Index. Patients } \\
\text { were contacted by telephone } \\
\text { interview to answer the } \\
\text { same questionnaires after } \\
36.0 \pm 17.0 \text { months. }\end{array}$ \\
\hline $\begin{array}{l}\text { Hammond et } \\
\text { al., } 2007\end{array}$ & 64 & $44 \%$ & NR & NR & $\begin{array}{l}\text { The patients' } r \text { subjective } \\
\text { assessment of their TMJ } \\
\text { status revealed that } 20 \\
\text { patients experienced mild } \\
\text { symptoms and } 2 \text { patients } \\
\text { experienced } \\
\text { symptoms. } \\
\text { severe }\end{array}$ \\
\hline
\end{tabular}


Amanda Phoon Nguyen and Ramesh Balasubramaniam / American Journal of Oral Medicine

(2016) Vol. 2 No. 1 pp. 26-42

\begin{tabular}{|c|c|c|c|c|c|}
\hline & & & & & $\begin{array}{l}\text { responded to a } \\
\text { questionnaire based on the } \\
\text { Helkimo Anamnestic } \\
\text { Dysfunction Index. This was } \\
\text { followed by a clinical } \\
\text { evaluation of mandibular } \\
\text { and TMJ functions. }\end{array}$ \\
\hline $\begin{array}{l}\text { Martinez- } \\
\text { Gomez et al., } \\
2010\end{array}$ & 40 & $26 \%$ & $\begin{array}{l}27 \% \text { prevalence } \\
\text { at } 14 \text { months. } \\
7 \% \text { prevalence } \\
\text { at } 58 \text { months. } \\
\text { One of the } 5 \\
\text { patients initially } \\
\text { diagnosed as } \\
\text { disc } \\
\text { displacement } \\
\text { with reduction. } 2 \\
\text { patients were } \\
\text { diagnosed as } \\
\text { disc } \\
\text { displacement } \\
\text { without } \\
\text { reduction and } 5 \\
\text { diagnosed as } \\
\text { muscle pain or } \\
\text { arthralgia } \\
\text { stopped using } \\
\text { the } \\
\text { because it was } \\
\text { ineffective. }\end{array}$ & $\begin{array}{lr}4.8 \text { years } \\
\text { (range, } & 3.6 \\
\text { to } & 5.8 \\
\text { years) } & \end{array}$ & 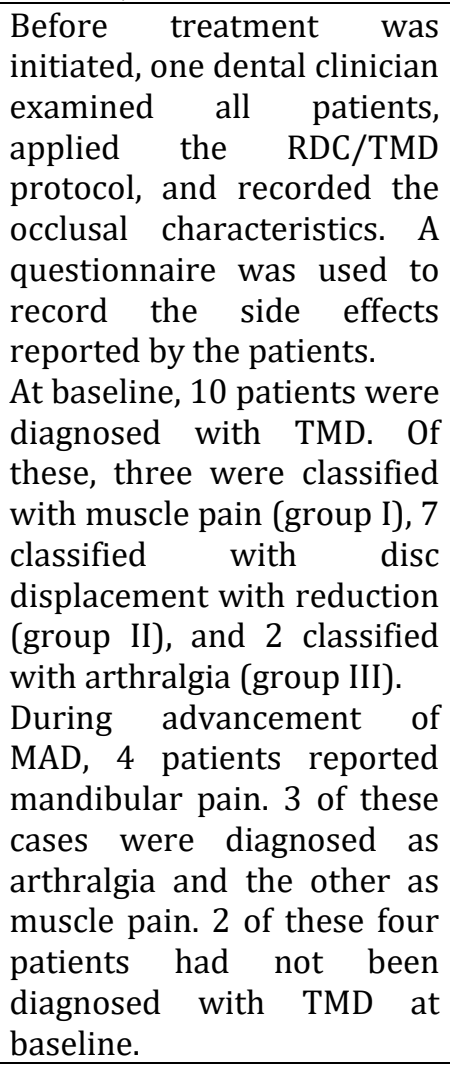 \\
\hline $\begin{array}{l}\text { Napankangas } \\
\text { et al., } 2012\end{array}$ & 15 & $20 \%$ & NR & NR & $\begin{array}{l}\text { Patients reported any } \\
\text { subjective symptoms they } \\
\text { experienced, such as pain in } \\
\text { the TMJ, difficulty in mouth } \\
\text { opening, TMJ } \\
\text { clicking/crepitation, and } \\
\text { TMJ locking/luxation. The } \\
\text { clinical stomatognathic } \\
\text { examination included } \\
\text { measurement of the ranges } \\
\text { of mandibular movements, } \\
\text { evaluation of deviation of } \\
\text { the mandible, evaluation of } \\
\text { TMJ and TMJ sounds. }\end{array}$ \\
\hline $\begin{array}{l}\text { Pantin et al., } \\
1999\end{array}$ & 132 & $26.5 \%$ & $6 \%$ & 5 years & $\begin{array}{l}35 \text { patients reported } \\
\text { temporomandibular joint } \\
\text { pain and } 33 \text { patients } \\
\text { reported muscle pain. }\end{array}$ \\
\hline
\end{tabular}




\begin{tabular}{|c|c|c|c|c|c|}
\hline & & & & & $\begin{array}{l}\text { Each patient answered a } \\
\text { questionnaire about the } \\
\text { occurrence of side effects. } \\
\text { A clinical examination } \\
\text { assessed the TMJ and } \\
\text { occlusal relationships. } \\
\text { Examination of the } \\
\text { temporomandibular joints } \\
\text { revealed noises in } 9 \text { of the } \\
106 \text { patients }(8 \%) \text { who did } \\
\text { not have joint noises prior to } \\
\text { treatment. }\end{array}$ \\
\hline $\begin{array}{l}\text { Perez et al., } \\
2013\end{array}$ & 167 & $19.8 \%$ & $11.2 \%$ & $\begin{array}{l}413 \text { days } \\
\text { (13.5 } \\
\text { months) }\end{array}$ & $\begin{array}{l}\begin{array}{l}\text { Patients were evaluated } \\
\text { clinical } \\
\text { and }\end{array} \\
\text { examinations anh } \\
\text { questionnaires, and TMD } \\
\text { was assessed using the } \\
\text { RDC/TMD criteria. } \\
\text { The prevalence of TMD was } \\
33 / 167(19.8 \%) \text { at baseline. } \\
\text { After an initial decrease to } \\
14.5 \% \text { after } 118 \text { days (visit } \\
\text { II), the prevalence increased } \\
\text { to } 19.4 \% \text { after } 208 \text { days } \\
\text { (visit III) and finally } \\
\text { demonstrated a decrease to } \\
8.2 \% \text { after } 413 \text { days (visit } \\
\text { IV). incidence of TMD was } \\
\text { The incis } \\
10.6 \% \text { after } 118 \text { days. This } \\
\text { decreased on further visits } \\
\text { and only } 2 \text { (1.9 \%) patients } \\
\text { developed TMD from visit III } \\
\text { to visit IV. }\end{array}$ \\
\hline
\end{tabular}

Legend: NR, not reported

There was substantial range in the prevalence of TMD signs and symptoms amongst studies included in this review. Across the eleven eligible studies, the average prevalence was found to be $25.6 \%$, though some studies reported incidences as high as $52 \%$, and as low as $0 \%$. As the different studies had different review periods, the initial time period refers to the duration post commencement of treatment of OSA with MAD, till the recall period with the studies' authors. The final time period refers to when that individual study was concluded. 
Amanda Phoon Nguyen and Ramesh Balasubramaniam / American Journal of Oral Medicine

(2016) Vol. 2 No. 1 pp. 26-42

Table 2 Percentage of Patients Discontinuing Treatment

\begin{tabular}{|c|c|c|}
\hline Studies & $\begin{array}{l}\text { \% Of patients } \\
\text { discontinuing } \\
\text { treatment }\end{array}$ & Additional Information \\
\hline $\begin{array}{l}\text { Almeida et al., } \\
2002\end{array}$ & $14 \%$ & $\begin{array}{l}\text { After } 40 \text { days, } 1 \text { of the } 7 \text { patients experienced persistent articular } \\
\text { pain of the TMJ region, despite adjustments in the MAD. } \\
\text { The patient was advised to discontinue MAD therapy and it } \\
\text { resolved after } 4 \text { weeks. MRI showed that in the patient with } \\
\text { articular pain, the condyle reached a more anterior compartment } \\
\text { while wearing the MAD, when compared to maximum mouth } \\
\text { opening. }\end{array}$ \\
\hline $\begin{array}{l}\text { Bondemark and } \\
\text { Lindman, } 2000\end{array}$ & $0 \%$ & $\begin{array}{l}\text { None of the patients showed more than five symptoms of } \\
\text { dysfunction either at the start of or after } 2 \text { years of treatment. It } \\
\text { was concluded that } 2 \text { years' treatment with a MAD had no } \\
\text { adverse effects on the craniomandibular status and function, but } \\
\text { the observed occlusal changes requires further evaluation. }\end{array}$ \\
\hline $\begin{array}{l}\text { Fritsch et al., } \\
2001\end{array}$ & $0 \%$ & $\begin{array}{l}\text { Side effects were common but only mildly disturbing, and all } \\
\text { patients wished to continue with MAD treatment. There was } \\
\text { measurable change in position of the teeth and of occlusion of } \\
\text { some patients. Severe discomfort or damage to the teeth or } \\
\text { temporomandibular joints that would have led to discontinuation } \\
\text { of therapy did not occur. }\end{array}$ \\
\hline Clark et al., 2000 & $49 \%$ & $\begin{array}{l}49 \% \text { of patients discontinued use of the device within } 3 \text { years. } \\
\text { Of the } 53 \text { responding patients, } 40 \% \text { reported jaw/facial muscle } \\
\text { pain, } 40 \text { percent had occlusal changes, } 38 \% \text { reported tooth pain, } \\
30 \text { percent reported jaw joint pain and } 30 \% \text { experienced } \\
\text { xerostomia. }\end{array}$ \\
\hline $\begin{array}{l}\text { Giannisi et al., } \\
2009\end{array}$ & $9.5 \%$ & $\begin{array}{l}\text { The authors noted no impairment to the TMJ in patients with OSA } \\
\text { presenting with mild TMD symptoms. Otological symptoms also } \\
\text { reduced during the period of this study. }\end{array}$ \\
\hline $\begin{array}{l}\text { Martinez-Gomez } \\
\text { et al, } 2010\end{array}$ & $62.5 \%$ & $\begin{array}{l}\text { In some patients, 5-year MAD use was associated with mild, } \\
\text { temporary subjective side effects and permanent occlusal } \\
\text { changes, mainly during the first } 2 \text { years. The use of the MADs did } \\
\text { not affect TMD prevalence. }\end{array}$ \\
\hline $\begin{array}{l}\text { Marklund et al., } \\
2004\end{array}$ & $24 \%$ & $\begin{array}{l}\text { Discomfort, including excessive salivation or a feeling of } \\
\text { awkwardness when wearing the MAD was the main cause of poor } \\
\text { adherence. Insufficient effect on snoring, odontologic problems, } \\
\text { periodontal disease and changes in occlusion during treatment } \\
\text { were some of the other explanations for poor adherence. }\end{array}$ \\
\hline $\begin{array}{l}\text { Pantin et al., } \\
1999\end{array}$ & $15 \%$ & $\begin{array}{l}7.5 \% \text { ceased because of side effects, } 6 \% \text { stopped because of pain } \\
\text { arising from the temporomandibular joint, facial muscles, or } \\
\text { teeth, and } 1.5 \% \text { because of occlusal change. }\end{array}$ \\
\hline Perez et al, 2013 & $49.1 \%$ & $\begin{array}{l}\text { By } 413 \text { days, } 49.1 \% \text { of patients had dropped out. The reasons } \\
\text { were not clear, however some patients reported the development } \\
\text { and persistence of jaw joint pain as well as muscle pain. }\end{array}$ \\
\hline $\begin{array}{l}\text { Ringqvist et al., } \\
2003\end{array}$ & $9 \%$ & $\begin{array}{l}4 \text { patients withdrew because they were not comfortable with the } \\
\text { MAD treatment. }\end{array}$ \\
\hline
\end{tabular}




\section{Amanda Phoon Nguyen and Ramesh Balasubramaniam / American Journal of Oral Medicine}

(2016) Vol. 2 No. 1 pp. 26-42

The prevalence of TMD after the initial phase of treatment, as noted on follow-up appointment/s and the percentage of patients who discontinued treatment revealed that the prevalence of TMD decreased. Across the studies, the adherence to MAD appears to vary, however from analysis, it appears an average $20 \%$ of patients discontinue MAD therapy over six to 120 months, and this number has been reported to be as high as $62.5 \%$ (over 58 months).

Table 3 Limitations of the Studies

\begin{tabular}{|c|c|}
\hline Paper & Limitations \\
\hline Almeida et al., 2002 & $\begin{array}{l}\text { This study had a small sample size. Due to polysomnographic expenses and lack of } \\
\text { patient adherence for many repeat sleep studies, the analysis of only seven } \\
\text { patients was completed. Treatment adherence could not be objectively verified. }\end{array}$ \\
\hline $\begin{array}{ll}\text { Bondemark } & \text { and } \\
\text { Lindman, 2000 } & \end{array}$ & $\begin{array}{l}\text { Poor reliability of the answers concerning subjective symptoms in the } \\
\text { questionnaire. } \\
\text { Patients reporting less than } 5 \text { symptoms were classified as having no TMD. } \\
\text { Treatment adherence could not be objectively verified. }\end{array}$ \\
\hline Clark et al., 2000 & $\begin{array}{l}\text { A more aggressive post-insertion recall program might have substantially } \\
\text { increased the adherence to treatment. } \\
\text { A majority of patients elected not to follow the authors' advice and participate in a } \\
\text { second, post-appliance sleep study. } \\
\text { Treatment adherence could not be objectively verified. }\end{array}$ \\
\hline Cunali et al., 2009 & $\begin{array}{l}\text { The sample size had a higher number of females than males, and their mean age } \\
\text { was relatively young ( } 47 \text { years old). } \\
\text { One dentist performed the diagnosis of TMD; independent confirmation of TMD } \\
\text { diagnosis by two dentists is desirable. } \\
\text { There is a lack of a control sample population matched for age and gender without } \\
\text { OSA. } \\
\text { Treatment adherence could not be objectively verified. }\end{array}$ \\
\hline Fritsch et al., 2001 & $\begin{array}{l}\text { Treatment adherence could not be objectively verified. } \\
\text { Two different devices were used: the Monobloc and the Herbst. }\end{array}$ \\
\hline Giannasi et al., 2009 & $\begin{array}{l}\text { Treatment adherence could not be objectively verified. } \\
\text { Patients reported wearing the appliance at least } 4 \text { nights a week. }\end{array}$ \\
\hline Hammond et al., 2007 & $\begin{array}{l}\text { There was a lack of a standardized pre-treatment TMJ assessment. } \\
\text { The small number of patients undergoing sleep studies and the different methods } \\
\text { of polysomnographic recordings limited the evaluation of the changes in } \\
\text { polysomnographic variables. } \\
\text { Treatment adherence could not be objectively verified. }\end{array}$ \\
\hline Marklund et al., 2004 & $\begin{array}{l}\text { The limitations of this study include selection of patients toward those with mild } \\
\text { disease, having patients who were no more than slightly over-weight, and having } \\
\text { the authors' own patients serve as their own controls in the study. } \\
\text { There was no full polysomnographic sleep recordings including EEG, but instead } \\
\text { the authors estimated sleep time from the respiratory sleep recordings and body } \\
\text { position sensors. } \\
\text { Treatment adherence could not be objectively verified. }\end{array}$ \\
\hline $\begin{array}{l}\text { Martinez-Gomez et al., } \\
2010\end{array}$ & $\begin{array}{l}\text { There was no control group. } \\
\text { It was difficult to know whether some of the adverse effects were related to the } \\
\text { use of an oral appliance. } \\
\text { Treatment adherence could not be objectively verified. }\end{array}$ \\
\hline Napankangas et al., & The limitations of this study are the small study sample and the lack of a control \\
\hline
\end{tabular}


Amanda Phoon Nguyen and Ramesh Balasubramaniam / American Journal of Oral Medicine

(2016) Vol. 2 No. 1 pp. 26-42

\begin{tabular}{|l|l|}
\hline 2012 & $\begin{array}{l}\text { group. } \\
\text { Treatment adherence could not be objectively verified. }\end{array}$ \\
\hline Pantin et al., 1999 & $\begin{array}{l}\text { There was failure to obtain follow-up information in 59 of the patients, and the } \\
\text { authors hypothesized that it is likely that they experienced side effects similar to } \\
\text { those studied. } \\
\text { Treatment adherence could not be objectively verified. }\end{array}$ \\
\hline Perez et al., 2013 & $\begin{array}{l}\text { Treatment adherence could not be objectively verified. } \\
\text { The authors were not able to determine reasons discontinued treatment. } \\
\text { Follow-up polysomnographic data to confirm the end-point of titration were not } \\
\text { available for most patients. Associated cost and lack of referring physician request } \\
\text { prohibited this procedure. This information would have been ideal to objectively } \\
\text { assess the adequate end-point of titration and overall success of MAD treatment. }\end{array}$ \\
\hline Ringqvist et al., 2003 & $\begin{array}{l}\text { Alimitation of the study was that these results could only be applied to adult male } \\
\text { patients with mild-to-moderate OSA using an appliance with 50\% advancement of } \\
\text { the mandible and a small vertical opening (3 mm, on average, between the incisal } \\
\text { edges). }\end{array}$ \\
\hline
\end{tabular}

\section{Discussion}

From our results of the studies evaluated, we concluded that MAD therapy for OSA appeared to be linked with TMD in a small and variable number of patients. It has been postulated that symptoms of TMD in patients undergoing MAD therapy were equivalent to that of a general population; however this review found the average TMD prevalence across the eleven studies was $25 \%$ of OSA patients (Hammond et al., 2007). TMD can affect $4 \%$ to $9 \%$ of the middle-aged general population (Cunali et al., 2009). It was also found that there was substantial diversity in the outcome measures used among eligible trials. Cunali et al in 2009 found a TMD prevalence of 52\% in their patients, the largest percentage across the studies evaluated. However, out of the 45 TMD patients, 13 were excluded: two due to diagnoses of other diseases, and 11 due to the fact that they did not return for a clinical exam. Of further interest, the authors suspected that eight patients did not fully comply with the treatment.

Bondemark in 1999 reported no significant TMD in their patients and concluded that two years' of treatment with a MAD had no adverse effects on the craniomandibular status and function. A small number of patients had tenderness to palpation of the masticatory muscles, most commonly the temporalis muscle; without reported TMJ locking or subluxation. The TMJ function showed minor differences before and after two years of treatment. TMJ sounds were found in nine patients before treatment and in twelve patients after the two-year treatment. It is evident that some changes had occurred among the patients during the two-year treatment period. While none of the patients had more than five symptoms, either at the start of treatment or after two years of treatment with the MAD, it is reasonable to conclude that TMD in their patients was likely present in a small number if evaluated using a different diagnostic criteria such as the DC/TMD.

Across the studies, TMD appears to be more common during the initial period of therapy, and its severity and duration varies widely. This is possibly due to different study designs. However, most studies reported that these adverse symptoms that appear in the initial phase of treatment are transient in a large number of affected patients, and there appears to be a trend of symptoms to decrease over time in the majority of patients. One study reported an improvement in TMD signs 


\section{Amanda Phoon Nguyen and Ramesh Balasubramaniam / American Journal of Oral Medicine}

(2016) Vol. 2 No. 1 pp. 26-42

and symptoms in some patients undergoing MAD therapy for OSA (Giannasi et al., 2009). In another study, the prevalence of orofacial pain increased with the use of MAD; however this study was based on a single question broad questionnaire and hence the results should be interpreted with caution (Vuorjoki-Ranta, 2014).

The most common TMD diagnosis was reported to be masticatory muscle pain with or without limited mouth opening, the most common subjective TMD symptom was TMJ clicking and/or crepitation and the most common clinical TMD sign was masticatory muscle pain, on palpation and function (Napankangas et al., 2012). Another study observed that low disability grade I (low disability and low-intensity pain) was the more frequent classification (Cunali et al., 2009). The studies used different criteria for assessment of TMD including some that use signs and symptoms to designate the diagnosis TMD. Hence it is difficult to subcategorize the TMD diagnosis into masticatory muscle pain, internal derangement, arthralgia or a combination of these diagnoses.

Despite the side effects of MAD therapy, some patients reporting symptoms related to TMD continued using a MAD (McGown et al., 2001). Other studies reported that patients with existing TMJ crepitation discontinue their MAD therapy more often than patients without this finding (Napankangas et al., 2012) Across the studies, the adherence to MAD appears to be variable. There also appears to be a declining trend of adherence over time (Cistullo et al., 2004). The adherence rate of MAD after one year ranged from 55\% to 82\% (Cistulli et al., 2004). From our results, it appears an average of $20 \%$ of patients discontinue MAD therapy over six to one hundred months, and this number has been reported to be as high as $62.5 \%$ (over fifty eight months) (MartinezGomis et al., 2010). Reasons given included the aforementioned side effects, social circumstances, as well as lack of perceived efficacy (Martinez-Gomis et al., 2010). Treatment for TMD should be considered, in particular for patients with pre-existing TMD symptoms, as treatment could prevent or reduce pain associated with TMD (Cunali et al., 2009)

A study compared TMD rates in patients with OSA being treated with MAD and CPAP (Doff et al., 2010). They noted that in the initial phase of treatment, TMD rates in patients using a MAD were 24\% higher than those using CPAP, and reported that while MAD therapy was associated in a shorttime follow-up with more pain-related signs and symptoms of TMD and increased TMJ pain compared with CPAP therapy, after one and two years a decrease of TMD was observed (Doff et al., 2010). The risk of developing pain and function impairment of the temporomandibular complex appear limited with long-term oral appliance use, and there were no limitations in mandibular function in both groups during the follow-up period (Doff et al., 2010) Because of the transient nature, the authors concluded that this pain is not a contraindication of oral appliance therapy in OSA patients (Doff et al., 2010). Although MAD and CPAP have been considered as alternative treatment pathways, there may be some scope for a patient to alternate between them as needed. There have been recent suggestions of combining the two treatment modalities simultaneously for additional benefit; the effect of MADs in opening the upper airway may reduce CPAP pressure, which may be desirable as high pressure requirement can lead to intolerance and reduced adherence in some patients (Vuorjoki Ranta, 2014).

There was difficulty in comparing the studies due to the differences in follow up time, methodology, sample size and diagnostic criteria. Some studies included patients with a previous history of TMD while some excluded them. The degree of initial mandibular advancement was set at different 


\section{Amanda Phoon Nguyen and Ramesh Balasubramaniam / American Journal of Oral Medicine}

(2016) Vol. 2 No. 1 pp. 26-42

percentages of maximum protrusion. The findings also suggest that standardized criteria for TMD diagnosis, such as the DC/TMD, should be part of the examination procedure and the use of such criteria to diagnose and establish the impact of TMD is imperative. This lack of criteria used in previous studies might explain why TMD is understated or overstated by both dentists and patients (Cunali et al., 2009) Independent confirmation of TMD diagnosis by two or more practitioners should be considered, as would comparison of the prevalence of TMD in a control sample population matched for age and gender without OSA. Longer clinical follow-up studies, with an objective method of monitoring patient adherence such as home monitoring devices, and preferably with a larger sample size are needed to evaluate the long-term effects of MADs on TMD.

\section{Conclusion}

The authors consider it prudent for clinicians to counsel patients that a small number will experience signs and symptoms of TMD with MAD use. However TMD is usually transient and the long-term risk appears small. Patients with pre-existing TMD should be treated prior to commencing MAD therapy. In patients who develop TMD during MAD therapy, treatment of their TMD is recommended to prevent discontinuation of MAD therapy. In a few patients, persistent TMD may result in discontinuation of MAD therapy. Patients should be cautioned of this possibility and subsequently referred to consider other treatment options for their OSA.

\section{Acknowledgments}

None

\section{Funding Source}

None

\section{Conflict of Interest}

None

\section{References}

Bondemark, L. \& Lindman, R. (2000). Craniomandibular status and function in patients with habitual snoring and obstructive sleep apnoea after nocturnal treatment with a mandibular advancement splint: a 2-year follow-up. The European Journal Of Orthodontics, 22(1), 53-60. http://dx.doi.org/10.1093/ejo/22.1.53

Bondemark, L. (1999). Does 2 years' nocturnal treatment with a mandibular advancement splint in adult patients with snoring and OSAS cause a change in the posture of the mandible? American Journal of Orthodontics And Dentofacial Orthopaedics, 116(6), 621-628. http://dx.doi.org/10.1016/S0889-5406(99)70196-4

Carrara, S, Rodrigues Contill, P, \& Stuginski Barbosa III, J. (2010). Statement of the 1st Consensus on Temporomandibular Disorders and Orofacial Pain. Dental Press Journal of Orthodontics, 15(3), 114-120. 


\section{Amanda Phoon Nguyen and Ramesh Balasubramaniam / American Journal of Oral Medicine}

(2016) Vol. 2 No. 1 pp. 26-42

http://dx.doi.org/10.1590/S2176-94512010000300014

Chan, A, \& Cistulli, P. (2009). Oral appliance treatment of obstructive sleep apnea: an update. Current Opinion In Pulmonary Medicine, 15(6), 591-596. http://dx.doi.org/10.1097/MCP.0b013e3283319b12

Chen, H, Lowe, A, de Almeida, F, Fleetham, J, \& Wang, B. (2008). Three-dimensional computer-assisted study model analysis of long-term oral-appliance wear. Part 2. Side effects of oral appliances in obstructive sleep apnea patients. American Journal Of Orthodontics And Dentofacial Orthopedics, 134(3), 408-417. http://dx.doi.org/10.1016/j.ajodo.2006.10.031

Cistulli, P, Gotsopoulos, H, Marklund, M, \& Lowe, A. (2004). Treatment of snoring and obstructive sleep apnea with mandibular repositioning appliances. Sleep Medicine Reviews, 8(6), 443-457. http://dx.doi.org/10.1016/j.smrv.2004.04.002

Clark, G, Sohn, J, \& Hong, C. (2000). Treating obstructive sleep apnea and snoring: Assessment of an anterior mandibular positioning device. Journal Of The American Dental Association, 131, 765-71. http://dx.doi.org/10.14219/jada.archive.2000.0275

Cunali, P, Almeida, F, Santos, C, Valdrighi, N, Nascimento, L, \& Dal'Fabbro, C. et al. (2009). Prevalence of Temporomandibular Disorders in Obstructive Sleep Apnea Patients Referred for Oral Appliance Therapy. Journal of Orofacial Pain, 23(4), 339-44.

de Almeida, F, Bittencourt, L, de Almeida, C, Tsuiki, S, Lowe, A, \& Tufik, S. (2002). Effects of mandibular posture on obstructive sleep apnea severity and the temporomandibular joint in patients fitted with an oral appliance. Sleep, 25(5), 507-13.

De Leeuw, R \& Klasser, G. D. (2013). American Academy of Orofacial Pain. Orofacial Pain: Guidelines for Assessment, Diagnosis, and Management. 5th ed. Quintessence, Chicago.

Doff, M, Finnema, K., Hoekema, A, Wijkstra, P, de Bont, L, \& Stegenga, B. (2012). Long-term oral appliance therapy in obstructive sleep apnea syndrome: a controlled study on dental side effects. Clinical Oral Investigations, 17(2), 475-482. http://dx.doi.org/10.1007/s00784-012-0737-x

Doff, M, Veldhuis, S, Hoekema, A, Slater, J, Wijkstra, P., de Bont, L, \& Stegenga, B. (2011). Long-term oral appliance therapy in obstructive sleep apnea syndrome: a controlled study on temporomandibular side effects. Clinical Oral Investigations, 16(3), 689-697.

http://dx.doi.org/10.1007/s00784-011-0555-6

Fransson, A, Tegelberg, Å, Leissner, L, Wenneberg, B, \& Isacsson, G. (2003). Effects of a Mandibular Protruding Device on the Sleep of Patients with Obstructive Sleep Apnea and Snoring Problems: A 2 Year Follow-Up. Sleep And Breathing, 7(3), 131-141.

http://dx.doi.org/10.1007/s11325-003-0131-7

Fritsch, K, Iseli, A, Russi, E, \& Bloch, K. (2001). Side Effects of Mandibular Advancement Devices for Sleep Apnea Treatment. American Journal of Respiratory and Critical Care Medicine, 164(5), 813-818. http://dx.doi.org/10.1164/ajrccm.164.5.2003078

Giannasi, L, Almeida, F, Magini, M, Costa, M, de Oliveira, C, \& de Oliveira, J. (2009). Systematic assessment of the impact of oral appliance therapy on the temporomandibular joint during treatment of obstructive sleep apnea: long-term evaluation. Sleep And Breathing, 13(4), 375-381. http://dx.doi.org/10.1007/s11325-009-0257-3

Hammond, R, Gotsopoulos, H, Shen, G, Petocz, P., Cistulli, P, \& Darendeliler, M. (2007). A follow-up study of dental and skeletal changes associated with mandibular advancement splint use in obstructive sleep apnea. American Journal Of Orthodontics And Dentofacial Orthopedics, 132(6), 806-814. http://dx.doi.org/10.1016/i.ajodo.2005.08.047

Holley, AB, Lettieri, CJ, \& Shah, A. (2011). Efficacy of an adjustable oral appliance and comparison with continuous positive airway pressure for the treatment of obstructive sleep apnea syndrome. Chest, 140,1511-1516. 


\section{Amanda Phoon Nguyen and Ramesh Balasubramaniam / American Journal of Oral Medicine}

(2016) Vol. 2 No. 1 pp. 26-42

http://dx.doi.org/10.1378/chest.10-2851

Jacobson, A. (2001). Treating obstructive sleep apnea and snoring: Assessment of ananterior mandibular positioning device. American Journal Of Orthodontics And Dentofacial Orthopedics, 119(1), 88. http://dx.doi.org/10.1067/mod.2001.111909

Johal, A, Fleming, P, Manek, S, \& Marinho, V. (2015). Mandibular advancement splint (MAS) therapy for obstructive sleep apnoea-an overview and quality assessment of systematic reviews. Sleep And Breathing, 19(3), 1101-1108. http://dx.doi.org/10.1007/s11325-015-1148-4

Marklund, M, Stenlund, H, \& Franklin, K. (2004). Mandibular Advancement Devices in 630 Men and Women With Obstructive Sleep Apnea and Snoring. Chest, 125(4), 1270-1278. http://dx.doi.org/10.1378/chest.125.4.1270

Marklund, M. (2015). Long-term efficacy of an oral appliance in early treated patients with obstructive sleep apnea. Sleep And Breathing, 20(2), 689-694 http://dx.doi.org/10.1007/s11325-015-1280-1

Martínez-Gomis, J, Willaert, E, Nogues, L, Pascual, M, Somoza, M, \& Monasterio, C. (2010). Five Years of Sleep Apnea Treatment with a Mandibular Advancement Device. The Angle Orthodontist, 80(1), 30-36. http://dx.doi.org/10.2319/030309-122.1

McGown, A, Makker, H, Battagel, J, L'Estrange, P, Grant, H, \& Spiro, S. (2001). Long-term use of mandibular advancement splints for snoring and obstructive sleep apnoea: a questionnaire survey. European Respiratory Journal, 17(3), 462-466. http://dx.doi.org/10.1183/09031936.01.17304620

Mehta, A, Qian, J, Petocz, P, Darendelilier, M, \& Cistulli, P (2001). A Randomized, Controlled Study of a Mandibular Advancement Splint for Obstructive Sleep Apnea. American Journal of Respiratory and Critical Care Medicine, 163(6), 1457-1461. http://dx.doi.org/10.1164/ajrccm.163.6.2004213

Michelotti, A, Alstergren, P, Goulet, J, Lobbezoo, F, Ohrbach, R, \& Peck, C. (2016). Next steps in development of the diagnostic criteria for temporomandibular disorders (DC/TMD): Recommendations from the International RDC/TMD Consortium Network workshop. Journal of Oral Rehabilitation, 43 (6), 453-467. http://dx.doi.org/10.1111/joor.12378

Näpänkangas, R, Raunio, A, Sipilä, K, \& Raustia, A. (2012). Effect of Mandibular Advancement Device Therapy on the Signs and Symptoms of Temporomandibular Disorders. Journal of Oral and Maxillofacial Research, 3(4), e5. http://dx.doi.org/10.5037/jomr.2012.3405

Ogawa, T, Ito, T, Cardoso, M, Kawata, T, \& Sasaki, K. (2009). Treatment using oral appliance for obstructive sleep apnea syndrome patients with multiple missing teeth. Sleep Medicine, 10(7), 809-811. http://dx.doi.org/10.1016/j.sleep.2008.10.003

Okeson, J.P. (1996). Orofacial Pain- Guidelines for Assessment, Diagnosis and Management in Orofacial Pain, Quintessence, Chicago.

Pantin, C, Hillman, D, \& Tennant, M. (1999). Dental side effects of an oral device to treat snoring and obstructive sleep apnea. Sleep, 22(2), 237-40.

Perez, C, de Leeuw, R, Okeson, J, Carlson, C, Li, H, Bush, H, \& Falace, D. (2013). The incidence and prevalence of temporomandibular disorders and posterior open bite in patients receiving mandibular advancement device therapy for obstructive sleep apnea. Sleep And Breathing, 17(1), 323-332. http://dx.doi.org/10.1007/s11325-012-0695-1 http://dx.doi.org/10.1007/s11325-012-0695-1

Phillips, B. (2006). Long-term Compliance and Side Effects of Oral Appliances Used for the Treatment of Snoring and Obstructive Sleep Apnea Syndrome. Yearbook Of Pulmonary Disease, 240-242. http://dx.doi.org/10.1016/S8756-3452(08)70197-X 


\section{Amanda Phoon Nguyen and Ramesh Balasubramaniam / American Journal of Oral Medicine}

(2016) Vol. 2 No. 1 pp. 26-42

Phillips, B. (2008). The effects of oral appliance therapy on occlusal function in patients with obstructive sleep apnea: A short-term prospective study. Yearbook Of Pulmonary Disease, 284-285. http://dx.doi.org/10.1016/S8756-3452(08)70710-2

Pliska, B, Nam, H, Chen, H, Lowe, A, \& Almeida, F. (2014). Obstructive Sleep Apnea and Mandibular Advancement Splints: Occlusal Effects and Progression of Changes Associated with a Decade of Treatment. Journal Of Clinical Sleep Medicine, 10(12):1285-1291 http://dx.doi.org/10.5664/jcsm.4278

Ramar, K., Dort, L., Katz, S., Lettieri, C., Harrod, C., Thomas, S., \& Chervin, R. (2015). Clinical Practice Guideline for the Treatment of Obstructive Sleep Apnea and Snoring with Oral Appliance Therapy: An Update for 2015. Journal Of Clinical Sleep Medicine. 1(7):773-827 http://dx.doi.org/10.5664/jcsm.4858

Richard, H, \& Claes, F. (2006). Treating severe obstructive sleep apnea syndrome (OSAS) with a mandibular advancement device (MAD). Sleep Medicine, 7, S95-S96. http://dx.doi.org/10.1016/j.sleep.2006.07.225

Ringqvist, M, Walker-Engström, M, Tegelberg, Å, \& Ringqvist, I. (2003). Dental and skeletal changes after 4 years of obstructive sleep apnea treatment with a mandibular advancement device: a prospective, randomized study. American Journal Of Orthodontics And Dentofacial Orthopedics, 124(1), 53-60. http://dx.doi.org/10.1016/S0889-5406(03)00240-3

Schiffman, E, Ohrbach, R, Truelove, E, Look, J, Anderson, G, \& Goulet, J. (2014). Diagnostic Criteria for Temporomandibular Disorders (DC/TMD) for Clinical and Research Applications: Recommendations of the International RDC/TMD Consortium Network* and Orofacial Pain Special Interest Group. Journal Of Oral \& Facial Pain And Headache, 28(1), 6-27. http://dx.doi.org/10.11607/jop.1151

Spencer, S, Cheng, A, Sambrook, P, \& Goss, A. (2015). A retrospective clinical study of mandibular advancement splint therapy for obstructive sleep apnoea - a 7 year review. International Journal Of Oral And Maxillofacial Surgery, 44, e290. http://dx.doi.org/10.1016/j.ijom.2015.08.327

Sutherland, K, Vanderveken, O, Tsuda, H, Marklund, M, Gagnadoux, F, Kushida, C, \& Cistulli, P. (2014). Oral Appliance Treatment for Obstructive Sleep Apnea: An Update. Journal Of Clinical Sleep Medicine. 10(2), 215-227. http://dx.doi.org/10.5664/jcsm.3460

Vanderveken, Olivier. (2016). The challenges of advancing the evidence for the long-term effectiveness of oral appliance therapy for sleep apnea. Sleep Medicine. 19, 128-130. http://dx.doi.org/10.1016/j.sleep.2015.08.011

Vuorjoki Ranta, T. (2014). Mandibular Advancement Device Therapy in Obstructive Sleep Apnea and Snoring in Community Dental Care: Two-year Follow-up Study on Self-reported Sleep Quality, Side Effects, and Compliance. Journal Of Sleep Disorders \& Therapy, 3:180. http://dx.doi.org/10.4172/2167-0277.1000180 